\title{
IMMORTALIZED CELL LINES FROM EMBRYONIC AVIAN AND MURINE OTOCYSTS: TOOLS FOR MOLECULAR STUDIES OF THE DEVELOPING INNER EAR
}

\author{
K. F. BARALD, ${ }^{*} \ddagger$ K. H. LINDBERG, K. HARDIMAN, $\dagger$ A. I. KAVKA $\ddagger$ \\ J. E. LEWIS, $\dagger$ J. C. VICTOR, C. A. GARDNER $\uparrow$ and A. PONIATOWSKI \\ Department of Anatomy and Cell Biology, University of Michigan Medical School, Ann Arbor, \\ MI 48109-0616, U.S.A.
}

\begin{abstract}
Recently, our studies have focused on genes expressed at the earliest stages of inner ear development. Our aim is to identify and characterize genes that are involved in determining the axes of the semicircular canals, in otic crest delamination and in early innervation of the inner ear. Many elegant studies of auditory development have been done in animal models. However, the need for large amounts of well-characterized embryonic material for molecular studies makes the development of otocyst cell lines with different genetic repertoires attractive. We have therefore derived immortalized otocyst cells from two of the most widely used animal models of ear development: avians and mice. Avian cell isolates were produced from quail otocysts (embryonic stage 19) that were transformed with temperature-sensitive variants of the Rous sarcoma virus (RSV). Among the individual transformed cells are those that produce neuron-like derivatives in response to treatment with $10^{-9} \mathrm{M}$ retinoic acid. Mammalian cell isolates were derived from otocysts, of 9 day (post coitus) embryos of the $\mathrm{H} 2 \mathrm{k}^{\mathrm{b}} t s \mathrm{~A} 58$ transgenic mouse (Immortomouse), which carries a temperature-sensitive variant of the Simian Virus 40 Tumor antigen. The vast majority of cells of the Immortomouse are capable of being immortalized at $33^{\circ} \mathrm{C}$, the permissive temperature for transgene expression, in the presence of $\gamma$-interferon. Several putative clones of these cells differentiated into neuron-like cells after temperature shift and withdrawal of $\gamma$-interferon; another isolate of cells assumed a neuron-like morphology on exposure to brain-derived neurotrophic factor even at the permissive temperature. We describe also a cell isolate that expresses the Pax-2 protein product and two putative cell lines that express the protein product of the chicken equivalent of the Drosophila segmentation gene engrailed. These genes and their protein products are expressed in specific subpopulations of otocyst cells at early stages. Both mouse and quail immortalized cell lines will be used to study inner ear development at the molecular level. (C) 1997 ISDN
\end{abstract}

Key words: cell lines; Pax-2; engrailed; inner ear; otocyst; mouse; quail.

The study of any tissue or organ system is enhanced by the availability of cell lines that retain differentiated properties. Cell lines that can be observed as they undergo tissue-specific differentiation from a proliferative to a differentiated state are especially valuable. Such cell lines can provide a

*To whom correspondence should be addressed at: Department of Anatomy and Cell Biology, University of Michigan Medical School, Box 0616, 5740 MSII Building, Ann Arbor, MI48109-0616, U.S.A.

†Developmental Neurobiology Program.

tCell and Molecular Biology Program.

§Present address: Dana Farber Cancer Institute,Harvard University, Boston, Massachusetts, U.S.A

$\uparrow$ Present address: Fogarty Institute, NIH.

Abbreviations: $\alpha$ Enhb-1, anti-engrailed antibody recognizing chick and mouse engrailed protein $1 ; \alpha-N F$, anti-neurofilament antibody; BDNF, brain-derived neurotrophic factor; BMP-4, bone morphogenetic protein-4; CD 1, outbred strain of mouse, Charles River Laboratories; chick En-1 and chick En-2, chick engrailed genes 1 and 2; CEF medium, chick embryo fibroblast growth medium**; DNA, deoxyribonucleic acid; DMEM, Dulbecco's minimal essential medium; DPBS/Ca, ${ }^{2+}$ Dulbecco's phosphate-buffered saline/(with calcium); DMSO, dimethyl sulfoxide; en, engrailed gene (or its protein product, en); $\alpha$ Enhb1, polyclonal antibody to the homeobox of the engrailed protein; FACS, fluorescence-activated cell sorter, in this case a Coulter Epics Elite; FBS, fetal bovine serum; F12, medium F12 (GIBCO/BRL); FITC, fluorescein isothiocyanate; $\gamma$ IFN, $\gamma-$ interferon; IMO, Immortomouse otocyst cell isolate (putative clone); number following designates specific clone or cell isolate, e. g. IMO-6; NGF, nerve growth factor; NF, neurofilament protein; NT3, neurotrophin-3; PA101, PA104 temperature-sensitive strains of Rous sarcoma virus; $P a x-2$, pair-rule gene, expressed in early otocyst, developing nervous system, kidney; (Pax-2, protein); PCR, polymerase chain reaction; PBS(T), phosphate-buffered saline (with triton X-100); RA, retinoic acid; RNA, ribonucleic acid; RSV, Rous sarcoma virus; $s r c$, sarc(oncogene); sQOTO-(x), e.g. sQOTO-2, clone number 2 of the src-transformed quail otocyst cell line; SV40, Simian Virus 40; Tag, T (tumor) antigen; TC, tissue culture; tsNY68, a temperature-sensitive variant of the New York version of the Rous sarcoma virus.

**Stage Chick Developmental Stages are according to Hamburger and Hamilton. ${ }^{31}$ 
source of tissue-specific RNA and are essential for analysis of transcriptional regulation of tissuespecific or developmentally regulated genes. Previous attempts to establish organ cultures from the auditory systems of chickens and mammals ${ }^{12,53,55,57,63,76}$ have been successful. However, except for the establishment of a middle ear cell line ${ }^{37}$ and a promising preliminary account of the development of stria vascularis and organ of Corti cell lines, ${ }^{48}$ no characterized cell lines from the inner ear have been reported in the literature.

We employed two alternative strategies in our attempts to develop auditory cell lines: (1) the derivation of quail otocyst cell lines src-transformed with temperature-sensitive variants of the Rous sarcoma virus (RSV), ${ }^{44,45}$ which have been used successfully by others to produce lines of immortalized neuroretinal cells $\mathrm{s}^{59}$; and (2) the derivation of conditionally immortalized cell lines from the Immortomouse, ${ }^{12,20,30,40} 42,48,52,60,61.78 .79$ which carries a temperature-sensitive variant of the SV40 T (tumor) antigen (Tag) transgene. ${ }^{41,42,52}$ Tag is under the control of a widely active promoter, which can be further induced by $\gamma$-interferon $\left(\gamma\right.$ IFN) ${ }^{41}$ Because the thermo-labile Tag is, in most cells, inactive at normal body temperature, the growth of tumors and the development of other abnormalities are minimized in vivo. Any protein made at the non-permissive temperature rapidly degrades in most cells, with the exception of thymocytes. Overgrowth of the thymus is a frequent cause of death among adult Immortomice, since the thymus fails to involute and its overgrowth interferes with diaphragm function, leading to eventual suffocation of the animals. However, when embryonic, neonatal or young adult tissues are excised and cultured in vitro in the presence of $y$ IFN at $33^{\circ} \mathrm{C}$, the oncogene is functional, and conditionally immortalized cell lines can be established. ${ }^{30,41}$ Thus, it is possible to immortalize both mixed cell populations ${ }^{40}$ and cloned cell lines $^{48}$ from the inner ear. These cell lines can be propagated while the Tag is active, then induced to differentiate with some degree of tissue-specificity at $37^{\circ} \mathrm{C}$ upon inactivation of Tag.

Cell lines from a number of different Immortomouse cell sources, including astrocytes ${ }^{30}$ skeletal muscle ${ }^{60}$ and osteoclasts, ${ }^{12}$ have been propagated successfully through as many as 100 generations. ${ }^{60}$ More importantly, these lines appear to be karyotypically stable, retaining properties at the ninetieth passage identical to those at the first. ${ }^{60,61}$

If immortalized cell lines are to be useful adjuncts to animal models and primary cell and organ cultures of the developing ear, several criteria must be satisfied: (1) the cells that are derived must have properties that closely resemble the cells of the developing embryonic otocyst and include a variety of representative auditory cell types which can be cloned and distinguished from one another; (2) they must express the genes that are responsible for morphological and functional development in the embryo; and (3) they must express these genes at the appropriate times and in the correct order in the course of their differentiation. If these criteria are met, then these cells should also express as yet unidentified genes that also play a role in ear development. The cell lines can then be used to identify and isolate such genes.

Pax-2 $2^{18,54,55,62}$ chick engrailed protein (ChickEn, referred to as en in this report) ${ }^{26,27,28,29}$ and neurofilament proteins ${ }^{72}$ have limited and interesting expression patterns in early embryonic development, including the developing otic placode ${ }^{18,54,55}$ and otocyst. ${ }^{54,55}$ These proteins are also expressed in a few of the cell isolates we have characterized. For example, in the embryo, transient expression of Pax-2 is found as early as stage $8-9^{31}$ ( $30 \mathrm{hr}$ after fertilization) at the midbrain/hindbrain junction (M. Goulding, personal communication), and persists at least through stage $13 .{ }^{54.55}$ (All staging of avian embryos in this report is according to the criteria of Hamburger and Hamilton. ${ }^{31}$ ) As development of the otocyst proceeds (stage 14), the protein level is still high in the rhombencephalic neural tube and in the ovoid half of the otic epithelium that is closest (i.e. medial) to the neural tube ${ }^{54,55}$ By stage 15 , the amount of Pax-2 protein has diminished considerably in the epithelial cells of the otocyst on the side that does not abut the neural tube and, by stage $15,{ }^{5,6-16}$ Pax-2 mRNA and protein expression have virtually disappeared from the cells on the side that does not make contact with the neural tube. ${ }^{54,55}$

The vertebrate engrailed-like (en) genes are a family of developmental genes that share sequence similarity with the Drosophila gene, engrailed.$^{16,21,26,33,39,46}$ En proteins act as transcription factors during development. ${ }^{26-28}$ Two en genes have been described in the chick, chick En-1 and chick En$2 .{ }^{16}$ We have characterized extensively the expression patterns of the chick En-1 and En-2 genes in the developing embryo at the mRNA and protein levels. ${ }^{26-29}$ The protein products of both of those genes are expressed in the developing otocyst at stage 19 [see Fig. 6(D)-(F)]. 
Neurofilament (NF) proteins are restricted to differentiated neurons and can, in general, be used as markers for post-mitotic, differentiated neuronal cells. ${ }^{72}$

Pax-2, en and NF proteins are expressed differentially in subpopulations of otocyst cells or their derivatives during development and each protein is expressed selectively in specific Immortomouse otocyst cell isolates we have characterized. We have also found a putative Immortomouse cell line (cell isolate) that responds to brain-derived neurotrophic factor (BDNF), ${ }^{720 a .75}$ by assuming a neuron-like morphology. BDNF is an important neurotrophin in the development of the auditory system. ${ }^{20 a .75}$ The neurotrophins BDNF and NT3 (neurotrophin-3) both affect the development of cells of the inner ear. ${ }^{20 a .24}$ Each of these neurotrophins has a number of different effects on the cells

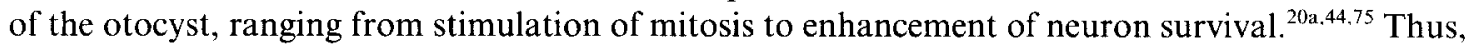
we believe that individual cell lines can be derived with properties resembling those of embryonic otocyst cells.

\section{EXPERIMENTAL DESIGN}

\section{src-Transformed quail cell line derivation}

Avian embryos have been the objects of early inner ear development studies for many years. ${ }^{24}$ They are ideal for studies involving transplantation of embryonic material and for the preparation of both dissociated cell cultures and organ cultures. All stages of ear development from otic placodes $^{54,55}$ to isolated postnatal inner ears that can undergo regeneration ${ }^{63}$ have been placed successfully in culture. However, the amount of material at very early developmental stages that is available either for primary culture or for molecular studies (e.g. RNA isolation for Northern blots) is limited. Therefore, production of cell lines has been attempted, using the transforming ability of viruses bearing specific oncogenes to immortalize otocyst cells. We have applied this approach to two widely used developmental models of ear ontogenesis, birds and mice.

In avian species, the RSV, with its transforming oncogene $s r c$, has been the primary means of producing cell lines from bird tissues. ${ }^{44,45,59}$ Although RSV infection of primary cultures of chick cells is possible, immortalization of chick cells in culture is not possible with RSV. ${ }^{44,45.59}$ However, the $\operatorname{src}$ oncogene easily transforms primary quail cells of comparable developmental stages, ${ }^{44,45,59}$ allowing the production of immortalized cell lines (albeit of limited propagation potential). Therefore, we chose to immortalize quail cells with either of two temperature-sensitive variants of RSV, the PA101 and PA104 RSVs. ${ }^{44,45,59}$ Since these mutant RSV strains do not infect either quail or chick embryos at normal avian body temperature $\left(41^{\circ} \mathrm{C}\right)$, the transformed quail otocyst cells bearing any gene of interest also can be used for transplantation into chick hosts with limited transmission of virus to adjacent cells.

The chimaeric embryo transplant models of LeDouarin's group ${ }^{14}$ form a precedent for these studies. Quail material transplanted into chick hosts develops normally and the quail cells can be traced in the chick host throughout their development. ${ }^{14}$ Feulgen staining can be used to label the condensed heterochromatin in the quail nuclei, ${ }^{14,27}$ antibodies to quail cells (Carlson and Carlson, unpublished) can distinguish them from cells of the host (chick).

Quail cells treated with either the PA101 or PA104 RSV ${ }^{44,45,59}$ at the permissive temperature $\left(36.5^{\circ}\right.$ ) are transformed, grow rapidly and are not contact-inhibited; those at the non-permissive temperature differentiate normally into cells with epithelial, neuronal and fibroblastic morphologies. The RSV infection induces both proliferation and transformation of these cells, but because the virus is defective ${ }^{44,45,59}$ the growth rate is twice as slow as growth rates found after transformation with, e.g. the tsNY 68 strain of the virus. ${ }^{44.45 .59}$

\section{Immortomouse cell line derivation}

Our object was to produce immortalized mammalian cell lines from very early otocysts, at times well before specialized cell types are morphologically distinguishable, and before otic crest delamination has occurred. We wanted also to obtain the widest possible repertoire of prospective cell types at times when otocyst cells have large developmental potential and plasticity, but at times when sufficient cell numbers can be harvested to make it possible to obtain enough cells from a single mating of Immortomouse male mice to outbred CD1 female mice. We chose, therefore, the 
9.5 day (p.c.) embryo because the otic pit has closed to form the otocyst and the otic $\mathrm{crest}^{34}$ has not yet delaminated. Also, based on our other studies of early gene expression in the developing placode and otocyst, we expected most of the cells at this stage to be at least multipotent. ${ }^{54}$ Both mouse strains were obtained through Charles River, U.S.A.; Immortomice were obtained by the permission of the Ludwig Institute, London.

\section{EXPERIMENTAL PROCEDURES}

\section{Production of quail cell mixed populations}

Quail (Coturnix coturnix japonica) eggs were obtained from Dave's Eggs and Poultry, Ann Arbor, MI, U.S.A., and were maintained in a forced draft incubator (Favorite) at $40^{\circ} \mathrm{C}$. Embryos were staged $^{31}$ and otocysts removed at stage 19 . The otocysts were dissociated with trypsin-EDTA (GIBCO/BRL) and plated on $50 \mathrm{~mm}$ (Falcon) tissue culture dishes in chick embryo fibroblast culture medium (CEF) medium (see below). Some plates were coated with rat tail collagen before plating cells. After 3 days in culture, the dissociated quail otocyst cells were transformed with the PA101 or PA104 ts RSV. $44,45,59$

\section{Cloning of quail otocyst cells by limiting dilution}

Quail cell clones were obtained by limiting dilution ${ }^{36}$ and seeded into 96-well (Costar) plates on day 6 after transformation. $s r c$-Transformed quail otocyst dissociated cultures were passaged five times prior to cloning. Once clones were obtained, the cells were frozen in $5 \times 10^{5}$ cell aliquots in 95\% fetal bovine serum (FBS) $/ 5 \%$ dimethyl sulfoxide (DMSO) (Sigma) and then thawed for subsequent propagation and analysis as needed.

\section{Immortomouse otocysts}

Embryonic otocysts derived from eight 9.5 days p.c. heterozygous Immortomouse $\times$ CD 1 embryos were excised and treated with trypsin-EDTA at $33^{\circ} \mathrm{C}$ for $15 \mathrm{~min}$. Dissociated cells were then plated on rat tail collagen-coated $60 \mathrm{~mm}$ tissue culture plastic dishes (Coming) in antibioticfree CEF medium containing $100 \mathrm{U} / \mathrm{ml} \gamma \mathrm{IFN}$ (GIBCO/BRL) at $33^{\circ} \mathrm{C}$.

Cultures of mixed cell types (uncloned) were propagated in this medium for 30 days and then frozen in aliquots in FBI/DMSO as described above. They were subsequently thawed, propagated and characterized. All passage numbers were recorded. Mixed cell cultures were grown in 25 $100 \mathrm{U} / \mathrm{ml} \gamma \mathrm{IFN}$ in simple medium (chick embryo fibroblast growth medium; CEF), without antibiotics, because of the potential ototoxicity of streptomycin-, kanamycin- or gentamycin-containing medium.$^{58}$ Cultures of mixed cells and cell isolates were analyzed with appropriate antibodies and probes as described below to identify cell characteristics.

\section{Cloning of Immortomouse otocyst cells by limiting dilution and by cell sorting}

Cloning of Immortomouse cells was done by two methods: two clones were obtained by limiting dilution cloning.$^{36}$ Fluorescence activated cell sorter (FACS) cloning was used to obtain 305 cell isolates. Sorting was done in the University of Michigan Flow Cytometry laboratory on an Epics Elite flow cytometer. After determining the sizes of cells in the random population of mixed otocyst cells by light scattering, light scattering-based sorting was used to plate cells at one cell per well into 11 96-well TC plates and at two cells per well in a single plate. All cells were grown in CEF medium without antibiotics.

After verification of cell growth in the 96-well plates and growth of cells to near confluency (which required a different amount of time for each cell isolate), cells were removed from the 96-well plates with trypsin/EDTA and transferred first to $35 \mathrm{~mm}$ plates, and eventually to $100 \mathrm{~mm}$ plates. After from four to six passages, duplicate cell stocks were frozen from $100 \mathrm{~mm}$ plates and stored in liquid nitrogen.

Verification of the presence of Tag in the embryos and mixed cell cultures of otocysts from the Immortomouse

Verification of the presence of the Tag transgene was done by PCR. Primers (30mers) designed to recognize Tag were: sense: 5'-GCA ATC GAA GCA GTA GCA ATC AAC CCA CAC-3'; and 
antisense: 5'-GGA CCT TCT AGG TCT TGA AAG GAG TGC CTG-3', and were synthesized in the DNA Synthesis Core at the University of Michigan. Primer sequences were provided by Drs Jat and Noble, Ludwig Institute, London. The PCR conditions were: denaturation: $94^{\circ} \mathrm{C}, 1 \mathrm{~min}$; annealing and synthesis: $72^{\circ} \mathrm{C}, 2 \mathrm{~min}(30$ cycles). After removal of the otocysts, DNA isolated from residual material from each embryo was analyzed by PCR; the initial mixed cell cultures $\left(33^{\circ} \mathrm{C}\right)$ were also tested.

\section{Medium for cell growth and cloning}

Both quail and mouse otocyst mixed cell populations, clones and cell isolates were plated in CEF medium $^{44,45}$ that contained F12 (GIBCO/BRL) with $2 \%$ tryptose phosphate broth $(5029 \times$ stock, GIBCO/BRL), 5\% FBS (Atlanta Biologicals) and either 1\% chick serum (GIBCO/BRL) for quail cells or equine serum (HyClone) for mouse cells.

\section{Immunocytochemistry}

Mixed cell cultures, cell isolates or clones were plated in CEF on $35 \mathrm{~mm}$ TC plates (Falcon or Coming) or on 8-well glass-partitioned slides ( $\mathrm{Lux}$ ) and grown for $24 \mathrm{hr}$ to 10 days at either $33^{\circ} \mathrm{C}$ in the presence of $\gamma \mathrm{IFN}$ or at $37^{\circ} \mathrm{C}$ in the absence of $\gamma \mathrm{IFN}$, in the case of mouse cells, or at 37 or $41^{\circ} \mathrm{C}$ in the case of quail cells. Medium was removed and cultures were rinsed in Dulbecco's phosphatebuffered saline with $\mathrm{Ca}^{2+}\left(\mathrm{DPBS} / \mathrm{Ca}^{2+}\right)(\mathrm{GIBCO} / \mathrm{BRL})(4 \times 15 \mathrm{~min})$ and fixed in $4 \%$ paraformaldehyde in DPBS/Ca ${ }^{2+}(\mathrm{pH} 7.2)$ or ice-cold methanol $(\mathrm{MeOH})(20 \mathrm{~min})$. Cultures were rinsed $(4 \times 15 \mathrm{~min})$ in DPBS $/ \mathrm{Ca}^{2+}$ and subsequently labeled with a primary antibody (overnight at $4{ }^{\circ} \mathrm{C}$ ), followed by a fluorescein isothiocyanate (FITC)-conjugated secondary antibody ( $3 \mathrm{hr}$, room temperature) (Jackson ImmunoResearch). ${ }^{4 \cdot 6,26-29,38.49 .50}$ Controls included pre-immune serum (in the case of polyclonal antibodies), non-specific antibodies (in the case of monoclonals) and no primary antibody.

Anti-mouse neurofilament $M$ subunit polyclonal antibody (Chemicon) was used at a 1:100 dilution, and assayed by previously published methods. ${ }^{49} \mathrm{~A}$ polyclonal antibody to Pax-2 protein was supplied by Dr Greg Dressler (HHMI, University of Michigan), and was used with a fluorescein conjugated goat anti-rabbit secondary (Jackson ImmunoResearch). An antibody to the mouseengrailed (en) protein $\left(\alpha\right.$ Enhb-1) was the gift of Drs Clay Davis and Alex Joyner ${ }^{16}$ (NYU) and was used according to our previously published procedures. ${ }^{26,27,28,29}$ For $\alpha$ Enhb-1, which was used to recognize chick and quail En-1 protein in whole mounts, embryos were fixed and stained according to previously published procedures ${ }^{26,27,28,29}$ and material sectioned as described below. Cultured cells were also characterized with antibodies for post-translationally modified $\alpha$ - and $\beta$-tubulins. These proteins are found more commonly in neurons than in other cells ${ }^{81,82}$ and serve as good markers for neuronal cell types. These antibodies, including one to glutamylated tubulin, were the gift of Drs Annie Wolff, Béatrice de Nechaud, Philippe Denoulet and Francois Gros (College de France, Paris). ${ }^{81,82}$ Peroxidase-labelled secondary antibodies were used for visualization of these primary antibodies by our previously published methods. ${ }^{26,27,28,29}$

\section{Histology of chick embryos}

Fertile white Leghorn chicken eggs (Gallus gallus domesticus) were obtained from Dave's Eggs and Poultry, Ann Arbor, MI, U.S.A. All eggs were maintained in a force-draft incubator at 38$39^{\circ} \mathrm{C}$. Embryos were staged ${ }^{31}$ and prepared for whole mount immunolocalization ${ }^{26,27,28,29}$ of engrailed protein or for sectioning and subsequent labelling with antibodies to Pax- $2^{55}$ or NF. ${ }^{81,82}$ Embryos were embedded in TissuePrep 2 (Fisher Scientific). Embryo sections $(7-10 \mu \mathrm{m})$ were separated into alternate series so that adjacent sections were: (1) mounted without counterstain; or (2) mounted after counterstaining with hematoxylin and eosin.

\section{Addition of neurotrophic factors}

Recombinant human brain-derived neurotrophic factor ${ }^{7,15}$ (BDNF) was obtained from BioSource International (PHC7014), and was the homodimer of two 119 amino acid subunits. Between 0.01 and $1.0 \mathrm{ng}$ was added to Immortomouse otocyst cell isolates in CEF between 24 and $48 \mathrm{hr}$ after plating the cells with and without $\gamma$ IFN (murine recombinant from GIBCO/BRL) at the two 
temperatures. The cultures were left in this medium for $2-10$ days. All medium containing $\gamma$ IFN (at $25-100 \mathrm{U} / \mathrm{ml}$ ) was light-shielded with aluminium foil and used within three days of preparation.

The all-trans form of retinoic acid (RA) (Sigma) was added at a final concentration of $10^{-9} \mathrm{M}$ to quail and mouse otocyst cultures $24-48 \mathrm{hr}$ after plating and was replenished every $48 \mathrm{hr}$ for 2 10 days.

\section{Cell counts in BDNF-treated cultures}

Immortomouse cell cultures that were treated with BDNF were monitored for the appearance of neuron-like cells for $36 \mathrm{hr}$ after addition of $(0.01-1 \mathrm{ng} / \mathrm{ml})$ BDNF. Triplicate cultures were fixed in cold $\mathrm{MeOH}$ and stained with antibody to $\mathrm{NF}$ as described above. Six random fields (at $25 \times$ magnification) were counted in triplicate cultures, scoring for neurofilament-positive cells. The average of the neuron-like cell numbers in the three plates was determined and also used to calculate the standard error of the mean.

\section{RESULTS}

\section{Otocyst cell lines from quail}

Seven immortalized otocyst cell lines with interesting properties have been produced by stably transforming quail otocysts from embryonic 3 day (in ovo) quail embryos, stage ${ }^{31} 17-19$ with either the PA101 or PA104 modified temperature-sensitive (ts) variants of the Rous sarcoma virus. ${ }^{44,45,59}$ Transformed cells of the mixed cultures are illustrated in Fig. 1. Representative clones of these cells are illustrated in Fig. 2. A summary of the characteristics of these cloned cell lines can be found in Table 1 .

Although antibiotic ototoxicity is known to affect development of hair cells at later stages of development ${ }^{58}$ not enough is known about antibiotic ototoxicity in the very early developing otocyst. Therefore, we have derived five of these clones without antibiotics to avoid obtaining a non-random sample of cells, and antibiotics were not used in the majority of these cultures. Large numbers of cells were propagated by this method for RNA isolation, since the virus-infected cells have a doubling time of less than $19 \mathrm{hr}$. Cloned cell lines were identified with respect to cell type and characterized partially by antibody labelling.

\section{Longevity of the quail cell isolates}

We have maintained the cloned $s r c$-transformed quail cell lines for over 3 years, either in thawed or frozen state $\left(-143^{\circ} \mathrm{C}\right)$ and have subjected all of these cells to over 30 passages.
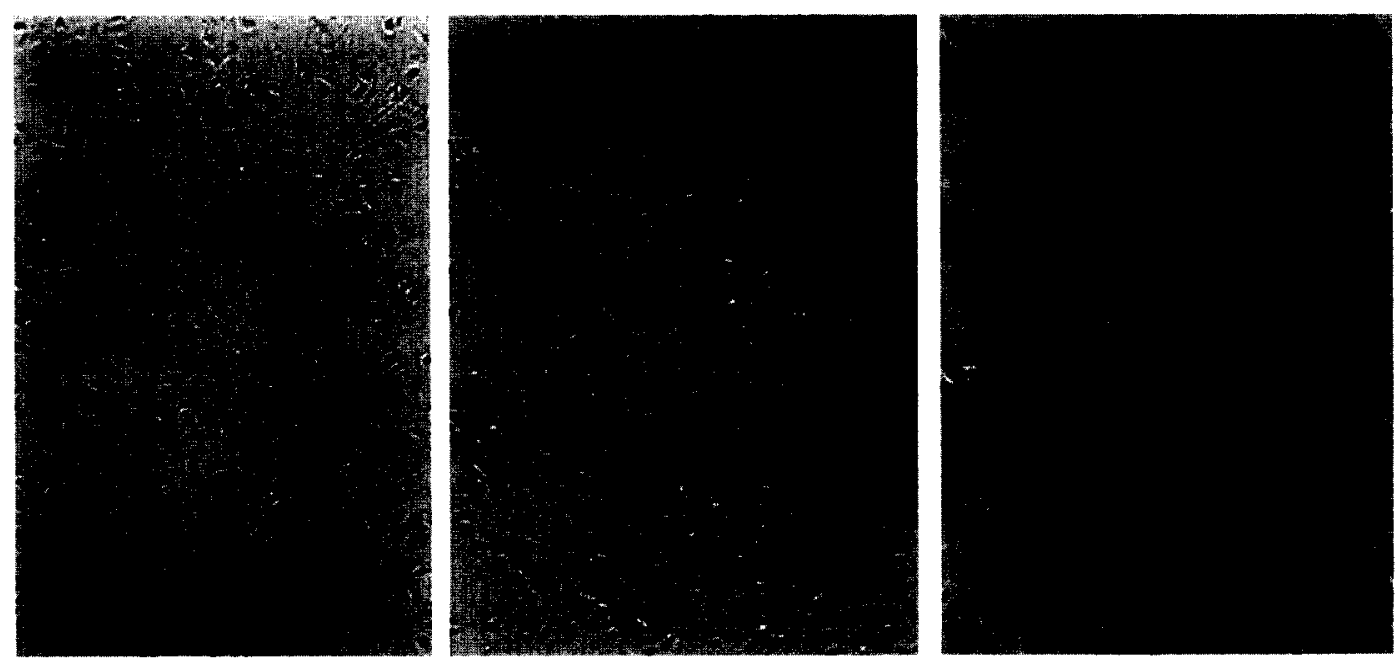

Fig. 1. (A) - (C) Dissociated src-transformed stage 19 quail embryonic otocysts grown in CEF (see methods) prior to cloning: (A) and (B) $(25 \times$ magnification); (C) $(60 \times$ magnification). Note that some of these cells have extensive processes (arrow) (C). 

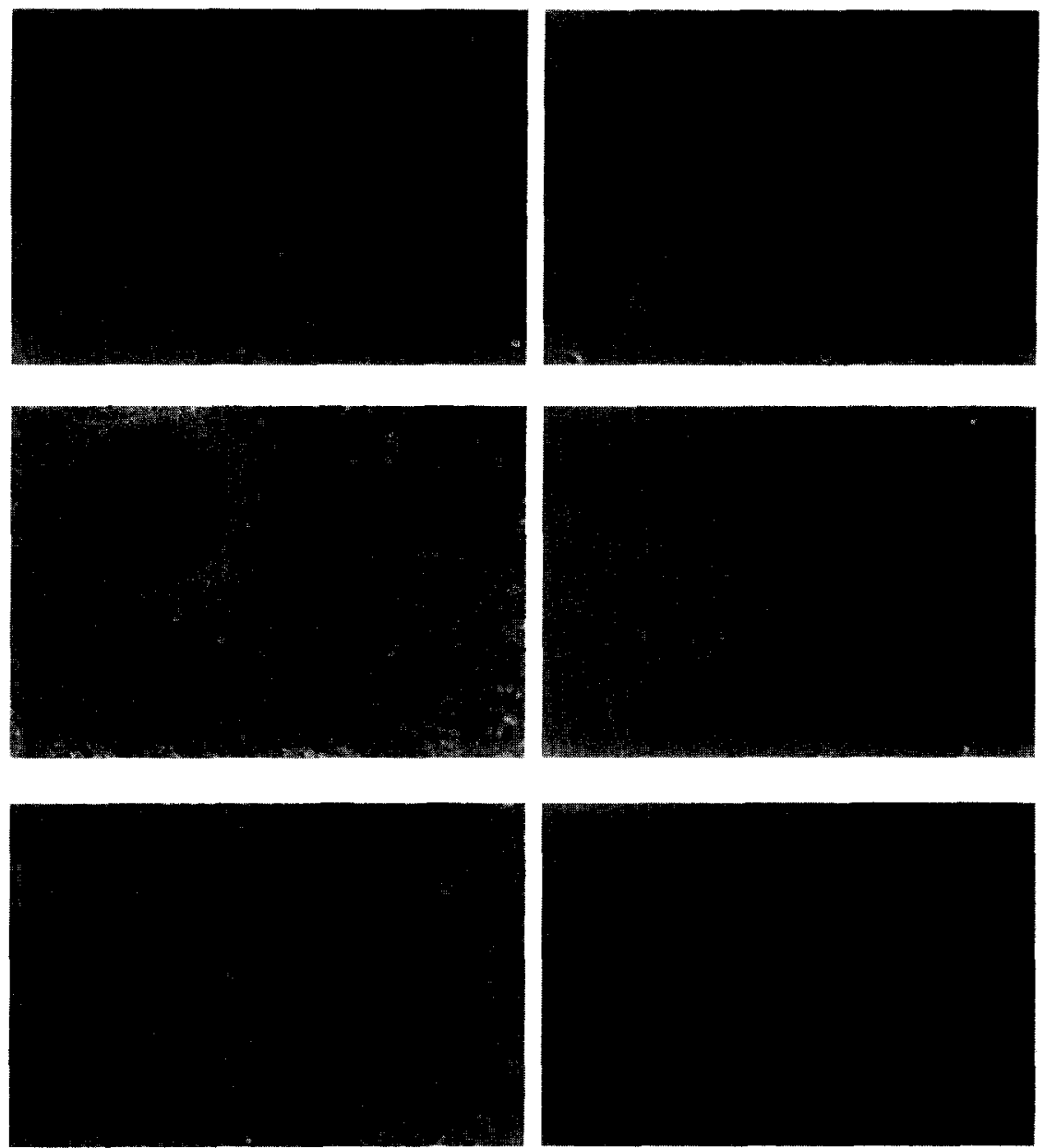

Fig. 2. (a) src-Transformed quail otocysts in mixed culture; (b)-(f) after cloning by limiting dilution. All cells are seen at the permissive temperature $\left(36.5^{\circ} \mathrm{C}\right)$. Cultures of otocyst-derived cells are seen in these $40 \times$ micrographs. The cells were photographed at 12 [(a), (e) and (f)] or $96 \mathrm{hr}[(\mathrm{b})$, (c) and (d)] after plating. (b) and (c) A melanocyte-like clone, sQOTO-8, with pigment seen in a cluster of the cells (arrow). (d) Clone sQOTO-4, a line with epithelial-like morphological properties in that they grow in flat sheets of closely adjoining "paving tile" configurations. (e) Clone sQOTO-2, is a clone of elongated cells, which appear to be fibroblast-like. (f) Clone sQOTO-7 is a cell line with complex processes. At the non-permissive temperature $\left(41^{\circ} \mathrm{C}\right)$, neuron-like cells appear which are neurofilament-positive (data not shown).

\section{A wide variety of morphological types can be seen in the cell isolates}

Quail cell lines. Of the eight putative cell lines derived from $s r c$-transformed quail otocysts, three of the cell lines appeared, on morphological criteria alone, to be epithelial in nature [e.g. see Fig. 2(d)], three were neuron-like [Fig. 2(f) and Fig. 3], one was a line of melanocytes [Fig. 2(b)] and the last resembled chick embryo fibroblasts [Fig. 2(e)]. One of the neuron-like cell lines is described in greater detail below. Table 1 summarizes the known properties of these cell clones.

\section{A quail otocyst cell clone assumes a neuronal morphology in the presence of retinoic acid}

One of the quail cell clones, sQOTO-5 [src-transformed quail otocyst line 5] became neuron-like after exposure to $10^{-9} \mathrm{M}$ retinoic acid (RA) [Fig. 3(B), (C) and (D)] for $24 \mathrm{hr}$. All of the cells were neurofilament positive after staining with the $\alpha$-NF antibody [Fig. 3(C)] and the cultures also expressed glytamylated tubulin in the same cells that expressed neurofilament [Fig. 3(D)]. These cells are being characterized further. It is interesting that the cells were converted to neuron-like cells even at the proliferative (permissive) temperature of $36.5^{\circ} \mathrm{C}$. A temperature shift to the nonpermissive temperature did not alter the number of cells that became neuron-like, but hastened the process. All of the cells in cultures grown at the non-permissive temperature $\left(41^{\circ} \mathrm{C}\right)$ became neuron- 
Table 1. Preliminary characterization of quail cell clones and Immortomouse cell isolates

\begin{tabular}{|c|c|c|c|}
\hline \multicolumn{4}{|c|}{$s r c$-Transformed quail otocyst cell clones (derived from stage 19 embryos) } \\
\hline Clone ( \pm antibiotic) & Phenotype at $36.5^{\circ} \mathrm{C}$ & $\begin{array}{l}\text { Effect of temperature shift to the } \\
\text { non-permissive } \mathrm{T}\left(41^{\circ} \mathrm{C}\right)\end{array}$ & Photograph in Fig. \\
\hline sQOTO-2(+) & Fibroblast-like & Not investigated & $2(\mathrm{e})$ \\
\hline SQOTO-4 (-) & Epithelial-like & Morphological change, but still epithelial & $2(d)$ \\
\hline sQOTO-3 (+) & Epithelial-like & Not investigated & \\
\hline sQOTO-7 (-) & & Neuron-like morphology & $2(\mathrm{f})$ \\
\hline sQOTO-5 (-) & & Neuron-like morphology (sensitive to RA) & $3(\mathrm{~A})-(\mathrm{D})$ \\
\hline SQOTO-6(-) & & Neuron-like morphology & \\
\hline sQOTO-8 (-) & Melanocyte-like & Melanocyte-like & 2(b) and (c) \\
\hline sQOTO-9 (-) & epithelial-like & Not investigated & \\
\hline \multicolumn{4}{|c|}{ Immortomouse cell isolates (derived from $9.5 \mathrm{~d}$ p. c. embryos) } \\
\hline Clone & Phenotype (at $33^{\circ} \mathrm{C}$ ) & $\begin{array}{l}\text { Effect of temperature shift to the } \\
\text { non-permissive } \mathrm{T}\left(37^{\circ} \mathrm{C}\right)\end{array}$ & Photograph in Fig. \\
\hline IMO-6 & Responds to BDNF & Neuron-like cells & $4(J) \div 5(F)$ \\
\hline IMO-36 & Expresses Pax-2 & Expresses Pax-2 & $5(\mathrm{D}) ; 6(\mathrm{~B})$ and $(\mathrm{C})$ \\
\hline IMO-109 & & Neuron-like cells & $5(\mathrm{~L})$ \\
\hline IMO-202 & Expresses en & Expresses en & $5(F) ; 6(E)$ and $(F)$ \\
\hline IMO-113 & Expresses en & Expresses en & $5(\mathrm{P})$ \\
\hline
\end{tabular}
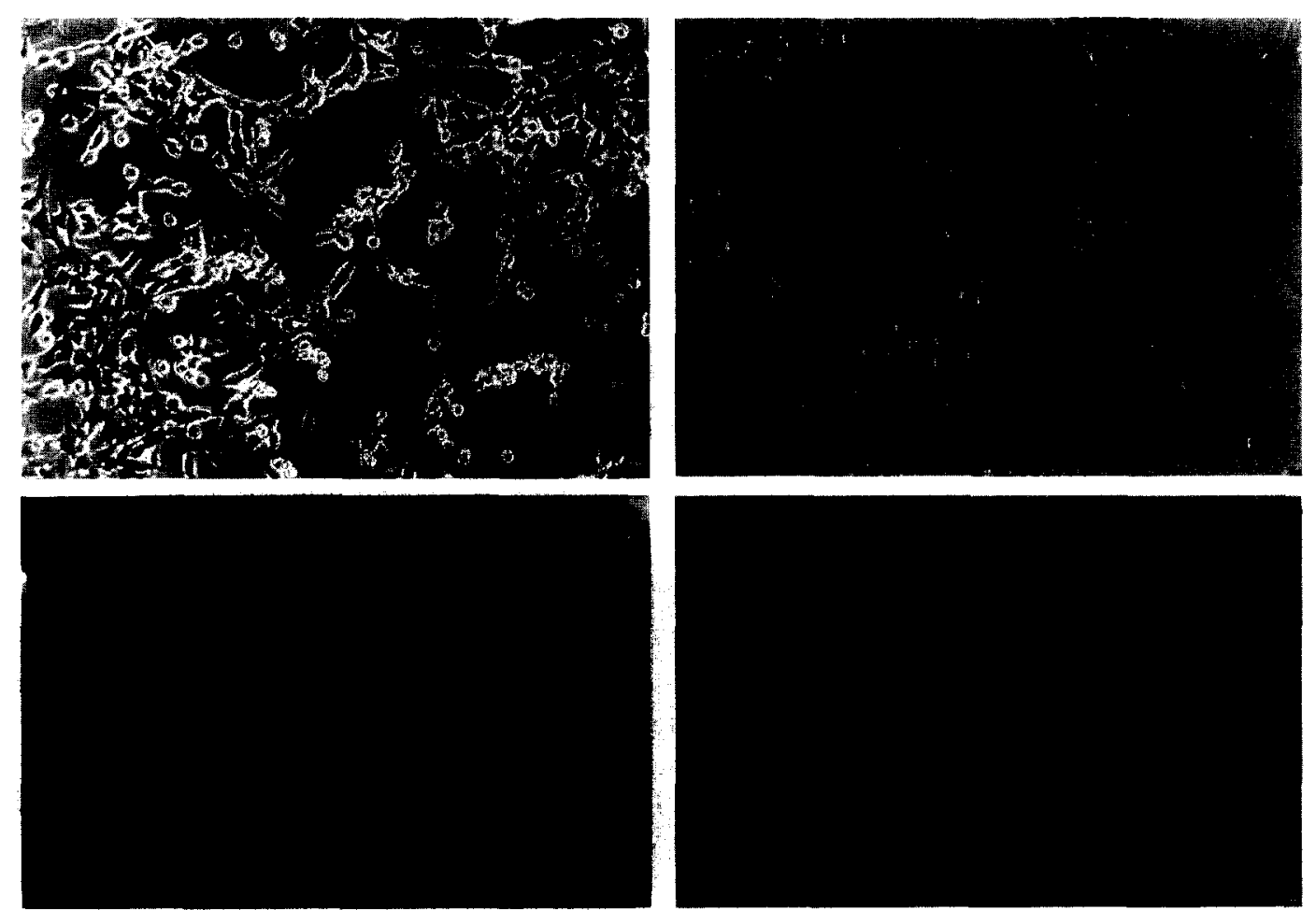

Fig. 3. Effect of $10^{-9} \mathrm{M}$ retinoic acid on the neuron-like development of a clone of $s r c$-transformed quail otocyst cells, sQOTO-5. (A) The sQOTO-5 grown in CEF (+ chick serum) at $36.5^{\circ} \mathrm{C}$ on TC plastic. The cells are highly proliferative on tissue culture plastic; none assume a neuronal morphology and none express NF or glutamylated tubulin (not illustrated). (B) Twenty-four hours after addition of RA to the cells at the permissive temperature $\left(36.5^{\circ} \mathrm{C}\right)$, the cells have assumed a neuron-like morphology. Because these cells are grown on TC plastic, the phase-bright neuron-like cells grow in clusters, with long processes extending from them. (C) The sQOTO-5 cells $16 \mathrm{hr}$ after addition of RA at the non-permissive temperature $\left(41^{\circ} \mathrm{C}\right)$. Precocious neuron-like differentiation and process extension are seen. The culture has been stained with anti-neurofilament antibody and a fluorescein-conjugated secondary antibody; every cell in the culture is stained with this antibody. (D) This is the same culture seen in (C). After permeabilizing the cell membranes by $\mathrm{MeOH}$ fixation, the cells subsequently were stained with the antibody to glutamylated tubulin, which labelled the same cells NF labelled in $(C)(40 \times$ magnification). 
like as early as $16 \mathrm{hr}$ after temperature shift and addition of RA [Fig. 3(B)]. A more detailed time study analysis of this conversion is under investigation.

\section{Immortomouse cell isolates}

Some of the many different cell types represented among the 307 cell isolates derived by FACS cloning from 9.5 days (p.c.) Immortomouse otocysts can be seen in Fig. 4. The cell isolates pictured here were grown at the permissive temperature for Tag expression and all were proliferative (although at very different rates). Polymerase chain reaction was used, as described in the Experimental procedures section, to verify that the transgene (Tag) was present in the DNA of residual embryonic material after otocyst removal and also was found in DNA from mixed cell isolates. The DNA from all eight embryos that were used to derive the cultures was Tag-positive, as was DNA from the mixed cultures.

The Immortomouse cell cultures have undergone between 20 and 47 passages, depending on the rate of growth of the mixed cell cultures and/or cell isolates and time frozen. As we have not unequivocally verified the clonal nature of the Immortomouse cell isolates produced by FACS sorting or limited dilution cloning described here, we prefer the term cell isolates to clones for these putative cell lines at this time. However, we believe all these lines to be clonal.

Whether these cells were grown on tissue culture plastic or on rat-tail collagen substrates made a great difference to the cell growth rates and to their morphologies [compare Fig. 5(G) and $(\mathrm{H})$ ]. Cells that were epithelial or neuronal in nature, but undifferentiated, grew more rapidly on TC plastic than they did on collagen. Average doubling times on TC plastic were $17 \pm 0.6 \mathrm{hr}$ (mean \pm SEM for 38 cell isolates) and $22.6 \pm 1.1 \mathrm{hr}$ for the same clones grown on collagen substrates $(n=3)$.

Because we chose a developmental time when we expected the majority of the otocyst's epithelial cells to be developmentally multipotent and plastic, ${ }^{54,55}$ we found it interesting that we derived large numbers of cell isolates with markedly different morphologies. Cells with different morphologies appeared in these cultures at the permissive temperature for transgene (Tag) expression, under conditions that encourage cell proliferation, not differentiation. Furthermore, the cells assumed different morphologies in the absence of the other Immortomouse cells in a simple medium, conditions under which differentiation should be minimal (Fig. 4). This result indicated that some putative cell lines were already committed to a given phenotype at this time, and could develop into markedly different cell types at the permissive temperature for transgene (Tag) expression.

In general, after the temperature shift from the permissive to the non-permissive temperature for Tag expression, cells that produced glia-like and neuron-like cell types at $37^{\circ} \mathrm{C}$ proliferated more rapidly on the rat-tail collagen-coated plates than on TC plastic. The doubling times for these cells were $18.6 \pm 1.5 \mathrm{hr}(n=6)$ on collagen substrates and $24.5 \pm 1.7 \mathrm{hr}$ on TC plastic for the neuron-like temperature shifted cells $(n=6)$. Epithelial and fibroblast like cells [e.g. those seen in Fig. 4(G) (I) and (L)] proliferated slightly more rapidly on tissue culture plastic than on collagen. However, the difference was not significant. The average doubling time for these cells on $\mathrm{TC}$ plastic was $18.1 \pm 0.7 \mathrm{hr}(n=4)$ and on collagen, $19.0 \pm 1.5 \mathrm{hr}(n=4)$. Differentiation of cell isolates that assumed a neuron-like morphology [e.g. Figure 5(B) and (E)] was more robust on rat-tail collagen substrates than on TC plastic. We have begun to test other substrates, including polyornithine, laminin and matrigel.

Change from the permissive to the non-permissive temperature for Tag expression causes differentiation of the Immortomouse cell isolates

When cultures of Immortomouse cell isolates were shifted from 33 to $37^{\circ} \mathrm{C}$ and $\gamma$ IFN was removed from the medium, a marked change occurred in many of the cell isolates (Fig. 5). Figure 5(A) and (B) are photos of two cultures of the same mixed cell population at 33 (A) and $37^{\circ} \mathrm{C}$, respectively. Another example illustrating the effect of temperature change and withdrawal of $\gamma$ IFN on cell differentiation is shown in Fig. 4(J) and Fig. 5(F). Figure 4(J) shows IMO-6 at $33^{\circ} \mathrm{C}$. No neuronlike cells are present at this temperature in CEF medium in $50 \mathrm{U} / \mathrm{ml} \gamma \mathrm{IFN}$. However, when the cultures are plated without $\gamma$ IFN at $37^{\circ} \mathrm{C}$ [Fig. 5(F)], in as little as $4 \mathrm{hr}$, neuron-like cells began to appear in the culture. In this photograph [Fig. 5(F)], we caught the transition between the nonneuronal cell variant commonly found at $33^{\circ} \mathrm{C}$ (the cells seen at the left of the photograph) and the neuron-like variant (seen with emerging processes at the right in the photograph) commonly found 

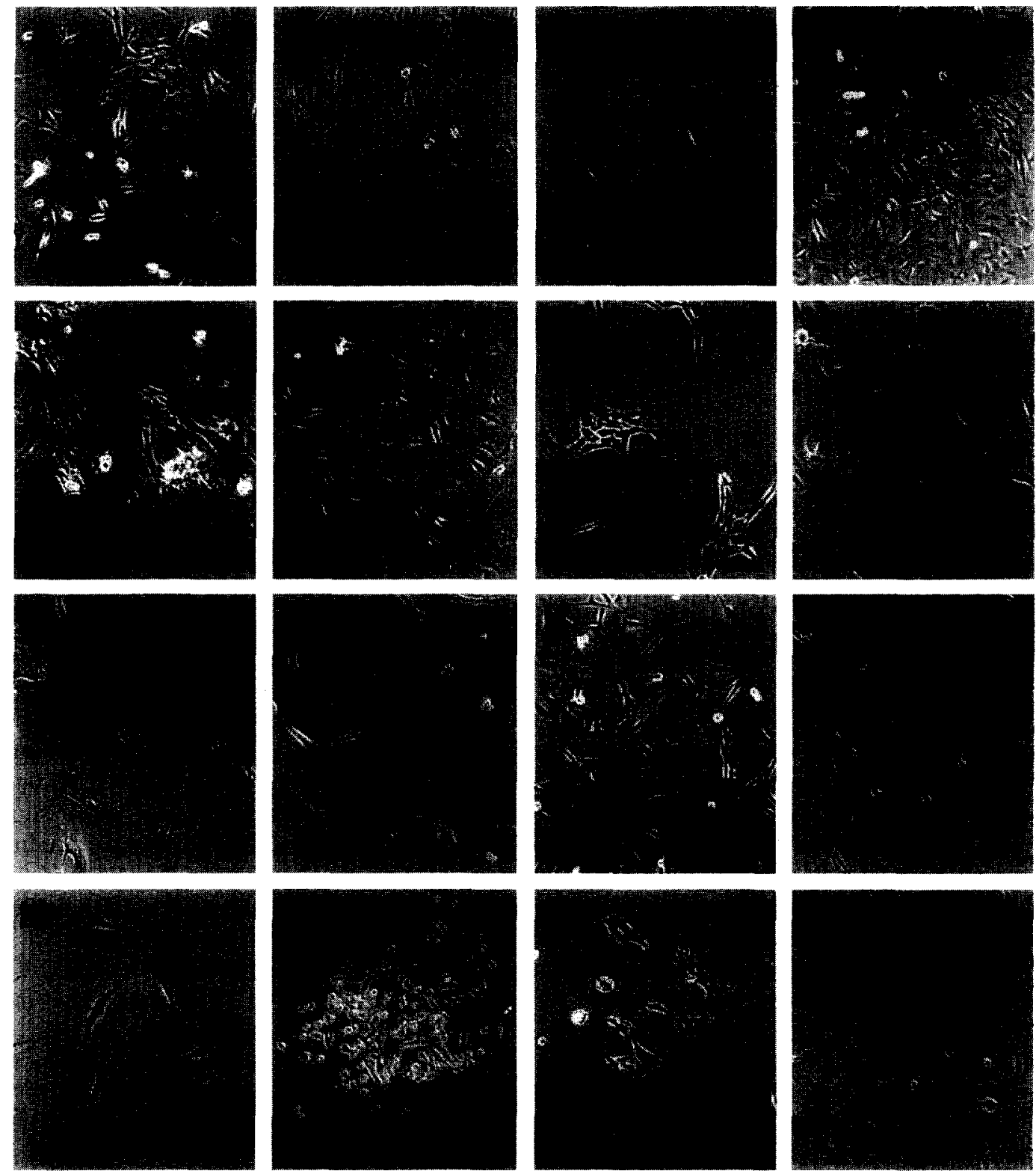

Fig. 4. Immortomouse cell isolates have many different morphologies. All of these cells were grown at the permissive temperature for transgene (Tag) expression, $33^{\circ} \mathrm{C}$, on tissue culture plastic in the presence of $50 \mathrm{U} / \mathrm{ml} \gamma \mathrm{IFN}$. All of these cell isolates have been in culture for between 24 and $96 \mathrm{hr}$. All are pictured at $25 \times$ magnification, photographed on a Leitz Diavert inverted microscope with phase-contrast optics. The cell isolates were cloned by fluorescence-activated cell sorter (a Coulter EPICS Elite) as described in the Experimental Procedures, except for that pictured in $(\mathrm{H})$, which was cloned by limiting dilution. The descriptions of the cell isolates in (A)-(P) are based solely on morphology. (A) IMO-7, containing fibroblastlike cells. (B) Another fibroblast-like isolate, IMO-59. (C) The IMO-44, very large cells with prominent stress fibers. (D) The IMO-36, Pax-2 expressing cell isolate [see Fig. 6(B) and (C)]. This cell isolate becomes neuron-like at $37 \mathrm{C}$, and was neurofilament positive at that temperature. (E) The IMO-76, epithelia-like cells that grow in small islands. (F) The IMO-202, fibroblast-like; expresses en [see Fig. 6(E) and (F)]. (G) The IMO-154, epithelia-like. (H) The IMO-188, epithelia-like cells with prominent nuclei that grow in very flat, paving-stone patterns. (I) The IMO-37, epithelia-like cells that grow in small islands. (J) The IMO-6, fibroblast-like cells at the non-permissive temperature, that become neuron-like at $37^{\circ} \mathrm{C}$; these cells are also responsive to BDNF. (K) The IMO-26 fibroblast-like cells. (L) The IMO-109, rounded cells that become neuronal at the non-permissive temperature. (M) The IMO-2, cells with thin cellular processes that grow very slowly. (N) The IMO-19, very small cells that do not attach well to TC plastic. (O) Cells resembling those in (C) above, but with much smaller cell bodies. (P) The IMO-113, another fibroblast-like cell isolate that becomes neuron-like at $37^{\circ} \mathrm{C}$. All of these cell isolates have been in culture between 24 and $96 \mathrm{hr}$. The scale bar in (M) refers to all magnifications and represents $50 \mu \mathrm{m}$. 

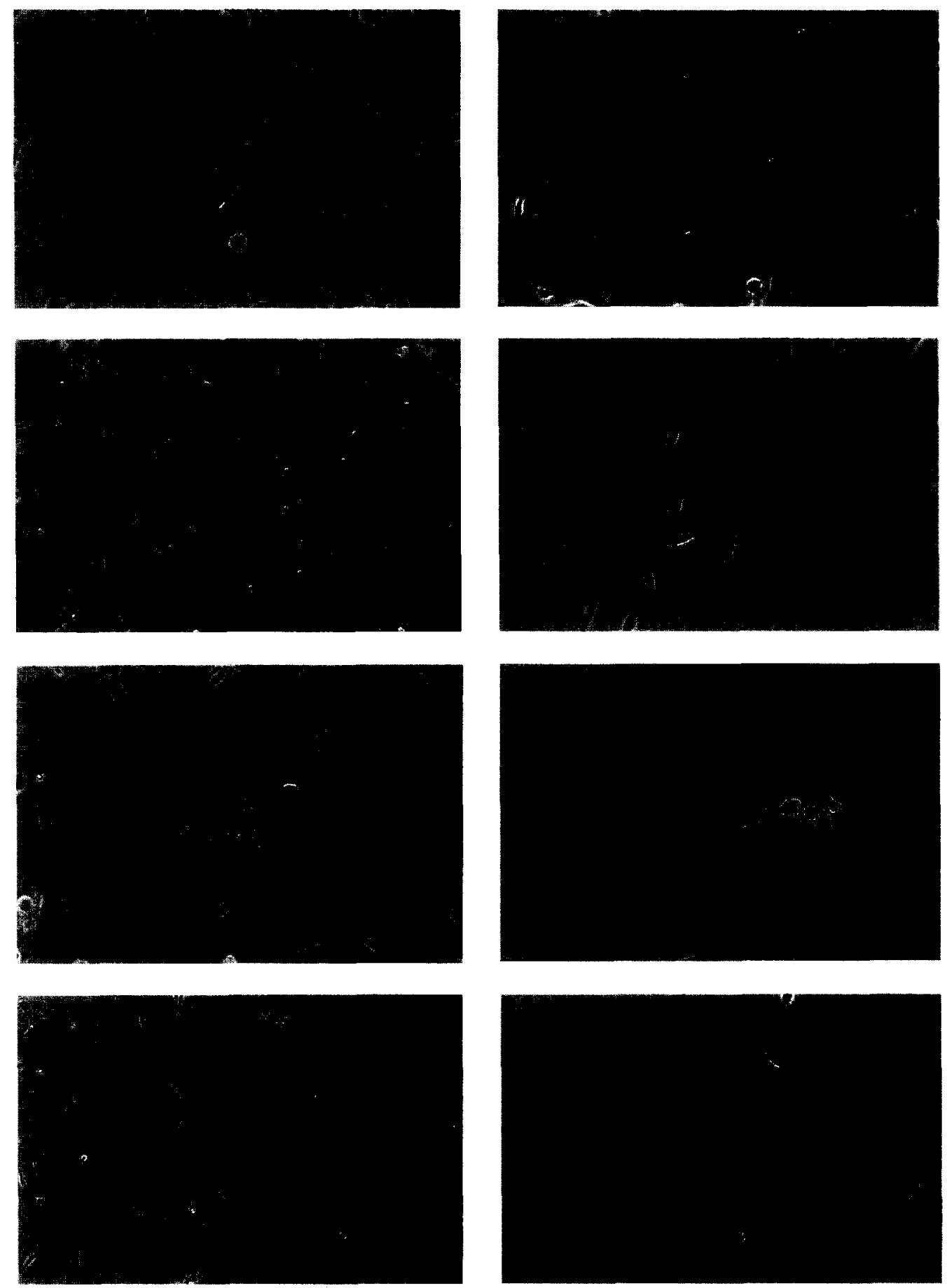

Fig. 5. Effect of temperature shift, alteration of medium conditions and two different substrates on Immortomouse mixed cell cultures and cell isolates. All are photographed with phase contrast microscopy, as described in the legend to Fig. 4. (A) Mixed cell culture grown on tissue culture plastic at $33^{\circ} \mathrm{C}(25 \times$ magnification), the permissive temperature for transgene expression, in the presence of CEF medium with $100 \mathrm{U} \gamma \mathrm{IFN} / \mathrm{ml}$. Note that a large number of different cell types is represented in this mixed culture, even at the permissive temperature. (B) Same mixed cell culture as seen in (A), has been plated in CEF medium without $\gamma \mathrm{IFN}$ at $37^{\circ} \mathrm{C}$ for $48 \mathrm{hr}$ on tissue culture plastic. Note the large number of neuron-like or glia-like cells in the culture at this time. (C) The fibroblast-like cell isolate [illustrated in Fig. 4(M) at $25 \times$ magnification]. Cells were grown on tissue culture plastic at $33^{\circ} \mathrm{C}$ for 4 days in the presence of $\gamma$ IFN. (D) The same cells seen in (C) are seen here at $40 \times$ magnification. (E) The cell isolate seen in (C) and (D) has been plated on tissue culture plastic at $37^{\circ} \mathrm{C}$ for 4 days in the absence of $\gamma \mathrm{IFN}$. Note that the same predominant cell type with processes seen in the mixed culture (B) is also seen in this culture. In neither case is the cell body phase-bright. Phase-bright cell bodies, such as those seen in Fig. 3(B,C) are common to neuron-like cells. Cells with phase-dark cell bodies that have processes such as these may be glia-like. (F) This cell isolate [the same as that pictured in Fig. $4(\mathrm{~J})$ ] has been grown for only $4 \mathrm{hr}$ at $37^{\circ} \mathrm{C}$ in the absence of $\gamma$ IFN. Note the emergence of phase bright neuron-like cells over even this short time. This cell isolate responds to BDNF (Fig. 7). (G) A cell isolate [the same one seen in Fig. 4(K)] grown for $48 \mathrm{hr}$ on tissue culture plastic at $37^{\circ} \mathrm{C}$ in the absence of $\gamma$ IFN. Note the elaboration of cell processes $(25 \times)$. (H) The same culture seen in $G$ at higher magnification $(40 \times)$, except that this culture was plated on rat-tail collagen and grown for $48 \mathrm{hr}$ at $37^{\circ} \mathrm{C}$ in the absence of $\gamma \mathrm{IFN}$. Cell process elaboration is enhanced on this substrate.

However, none of these cells is neurofilament-positive (data not shown). 
at $37^{\circ} \mathrm{C}$. By $16 \mathrm{hr}$ in culture at $37^{\circ} \mathrm{C}$, in the absence of $\gamma \mathrm{IFN}$, all of the cells had a neuron-like morphology and all stained with antibodies to neurofilament protein and to glutamylated tubulin (data not shown). Table 1 recapitulates the properties of these cell isolates.

\section{Immortomouse cell isolates express Pax-2 protein or en-protein products}

Pax-2 protein expression in the developing chick inner ear was found in all cells of the very early

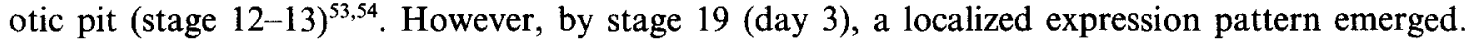
Those otocyst cells adjacent to the neural tube were labelled, but Pax-2 protein expression diminished in the more lateral cells (i.e. the side of the otocyst away from the neural tube) [Fig. 6(A)]. Although none of the quail otocyst cell clones we produced expressed Pax-2, IMO-36 expressed Pax-2 protein both before and after the shift from the permissive to the non-permissive temperature and withdrawal of $\gamma$ IFN [Fig. 6(B) and (C)].

Engrailed (en) protein was expressed by cells of the hindbrain and otocyst at stage ${ }^{31} 19$ in the chick and quail [Fig. 6(D)] and at comparable stages in the mouse. Engrailed protein expression in the chick otocyst was limited to a narrow band of cells in the otocyst at this stage. A comparable stage mouse embryo had a similar staining pattern. However, while none of the eight $s r c$-transformed otocyst cell lines expressed the en protein product, two of the IMO cell isolates expressed en protein. An example is seen in Fig. 6(E) and (F). The IMO-202 expressed en protein at both the permissive and non-permissive temperatures [see Fig. 6(E) and (F)]. As with Pax-2 expression, the protein product was found in the cell nuclei. Compare the staining of the polyclonal anti-mouse en antibody ${ }^{16}$ in Fig. 6(D), to the staining of the same antibody in the IMO cell isolates [Fig. 6(F)] at the nonpermissive temperature.

An Immortomouse cell isolate responds to treatment with BDNF by assuming a neuron-like morphology

BDNF is known to elicit a number of different responses in early developing cells of the auditory system, including mitogenesis and promotion of survival. ${ }^{20 a, 24,25,75}$ Receptors for this nerve growth factor (trkB) also have been found in tissues derived from the otic placode. ${ }^{24,25,75}$ We have recently reviewed what is known about the role of BDNF in development. ${ }^{24}$ One of the Immortomouse otocyst cell isolates, IMO-6 was responsive to BDNF at concentrations of between 0.01 and $1.0 \mathrm{ng} / \mathrm{ml} .^{75} \mathrm{In}$ response to as little as $0.01 \mathrm{ng} / \mathrm{ml} \mathrm{BDNF}$, all cells of this isolate assumed a neuronal morphology [see Fig. 4(J) and Fig. 5(F)] and became neurofilament-positive, even at the permissive temperature for Tag expression. Placing cells at $37^{\circ} \mathrm{C}$ and removing $\gamma \mathrm{IFN}$ hastened the total conversion of cells to a neuron-like morphology by $8-10 \mathrm{hr}$ (see Fig. 7). Without the addition of BDNF, temperature switch and removal of $\gamma$ IFN alone did not elicit neuronal conversion during the time period assayed. Thus, a putative signalling molecule for differentiation of at least one cell type has been found and future studies will focus on the presence of appropriate receptors for this molecule in the cell line.

\section{DISCUSSION}

\section{Developing conditionally immortalized mouse cell lines from the inner ear}

Our objective was to provide diverse otocyst cell lines with interesting and different morphologies for chimeric transplantation experiments, ${ }^{14-27}$ cDNA library productions, ${ }^{62}$ mRNA isolation and subtractive hybridization ${ }^{68}$ and differential display schemes (Lomax's paper and Ryan's paper, in this volume). Such approaches will allow us to discover which mRNAs might be either unique to, or enriched in, specific subpopulations of placodal cells and very early otocysts. If the cell lines fulfil their promise, they can be used to determine the type of experimental approaches that should be tried in the embryo, the ultimate test of functionality.

Genes expressed in the early developing otocyst are expressed in the cultured cells

Genes with early interesting expression patterns in ear development, such as Pax-2, ${ }^{18,54,55,62}$ and engrailed, ${ }^{26-29,56}$ are expressed in the otocyst cell isolates (Fig. 6). Both the Pax-2 and en proteins were confined to the nuclei of these cells, as expected for transcription factors. Early stage otocysts express Pax-2 and engrailed proteins in subsets of cells at the stage the otocysts were isolated. ${ }^{54,55}$ 

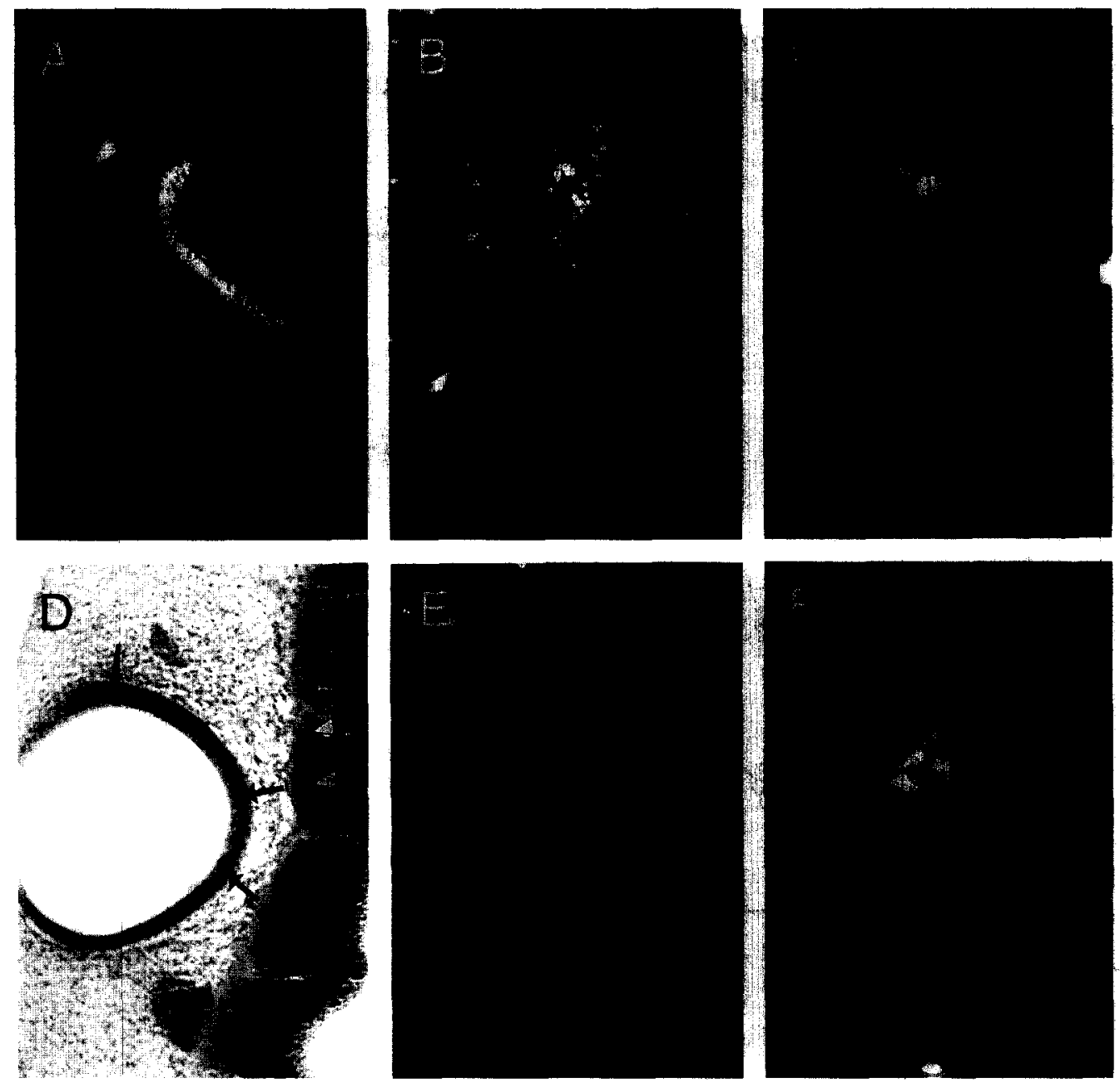

Fig. 6. Pax-2 (A)-(C) and engrailed (D)-(F) protein expression in developing otocysts and in Immortomouse otocyst cell isolates. Pax: (A) Fluorescence micrographs of chick embryo (stage 16) sectioned $(10 \mu \mathrm{m})$ through the otocyst. Pax-2 expression is predominantly on the medial side of the otocyst close to the rhombencephalon (arrow) (represented by the line of bright Pax-2 positive nuclei seen at the upper left). Each section was stained with a rabbit IgG polyclonal antibody to Pax-2 followed by a fluoresceinconjugated goat anti rabbit IgG secondary antibody. (B) Pax-2 protein expression in a cell isolate of Immortomouse cells, IMO-36, after $4 \mathrm{hr}$ at the non-permissive temperature $\left(37^{\circ} \mathrm{C}\right)$. Cells enlarge and transiently lose Pax-2 expression at the non-permissive temperature (arrow). Pax-2 protein is still present in the smaller cells as it is at $33^{\circ} \mathrm{C}$ in the cells before they change their morphology. The same antibody and staining procedure used on the tissue sections was used on the cultured cells. (C) The IMO-36 cells after $48 \mathrm{hr}$ at $37^{\circ} \mathrm{C}$ in medium without $\gamma \mathrm{IFN}$. The cells became larger and neuron-like; some have short and some have extensive neurite-like processes. These cells re-express Pax-2 protein. Staining was done by the same method as in (A) and (B). Magnification is $40 \times$. Engrailed: (D) Engrailed protein expression in a stage 19 chick embryo sectioned through the otocyst and rhombencephalon. En expression (arrows) is also largely medial in the otocyst at this level. The antibody and protocols for this staining are described in Experimental procedures. The secondary antibody is peroxidase-conjugated goat anti-rabbit IgG (Jackson). Note the nuclear deposition of en protein in the rhombencephalon (arrowheads), as well. (E) The IMO202 cells also express engrailed protein. Cultures were at $33^{\circ} \mathrm{C}$ in the presence of $50 \mathrm{U} / \mathrm{ml} \gamma \mathrm{IFN}$. The same primary antibody used in (D) was followed by a fluorescein-conjugated secondary antibody to reveal the nuclear localization of the en protein. (F) The IMO-202 cells continue to express engrailed protein at $37^{\circ} \mathrm{C}$ in the absence of $\gamma \mathrm{IFN}$. Cells also become larger in diameter. All IMO cells were at $40 \times$ magnification.

Therefore, expression of these proteins in specific subpopulations of IMO cells suggests that they represent distinct otocyst cell subpopulations. We have found only one Pax-2-expressing cell line so far. Only about one-half of the roughly 300 cell isolates putatively cloned by FACS have been analysed to date, and those cell isolates which appeared to be duplicates of one another by morphological criteria were not tested. However, if these cells were randomly representative of the cells of the otocyst, we would expect that about one-half of them would express Pax-2, and they did not. We also found two en-expressing cell isolates among the cells tested. Morphologically, these 


\section{Neuron-IIke Cells in IMO-16 in Response to $0.2 \mathrm{ng} / \mathrm{ml}$ BDNF and Temperature Shift}

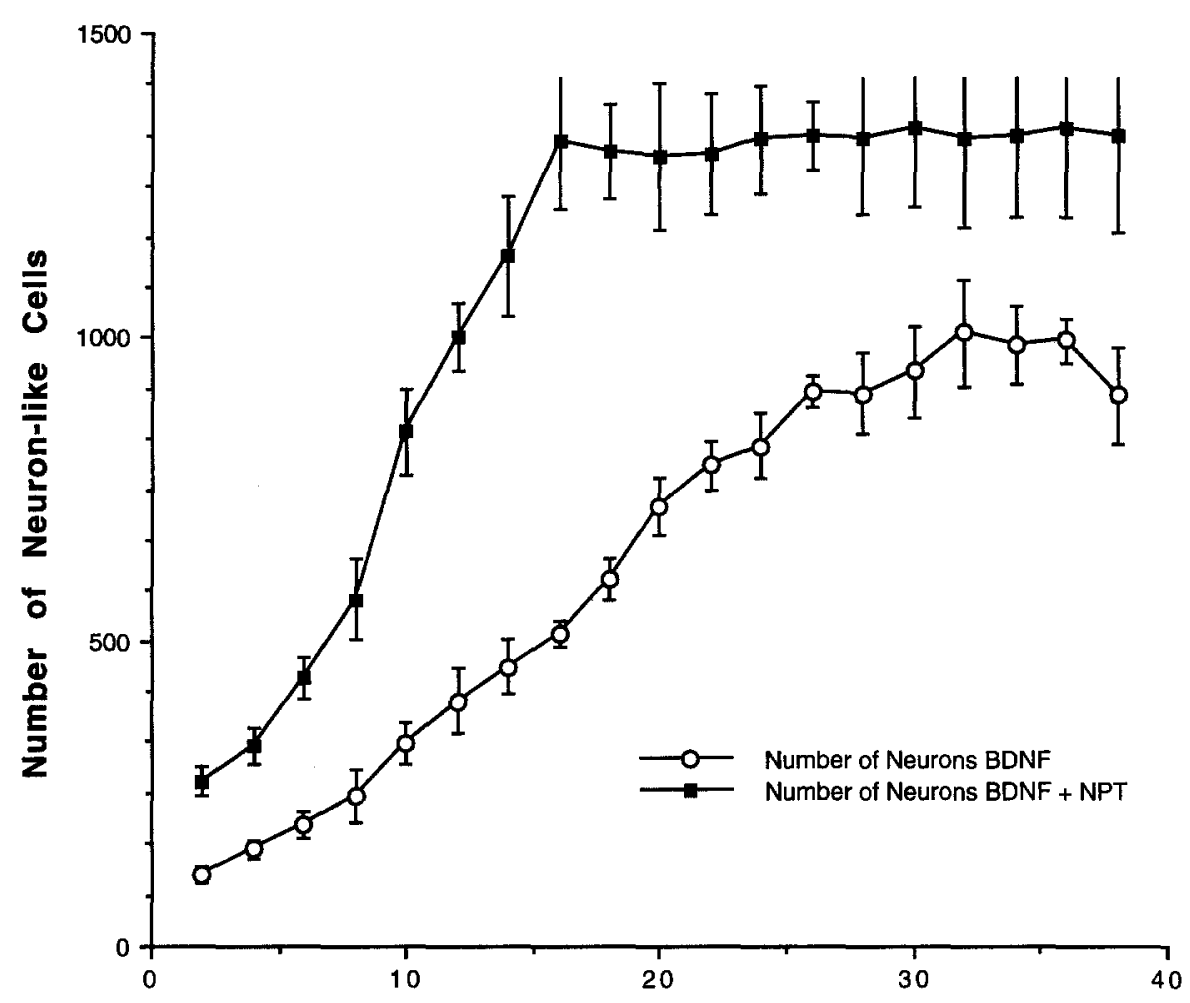

Time (hrs)

Fig. 7. Effect of BDNF and shift to the non-permissive temperature $\left(37^{\circ} \mathrm{C}\right)$ on the precocious development of neuron-like cells of the IMO-6 cell isolate. Open circles: development of neuron-like cells after addition of $\mathrm{BDNF}$ at the permissive $\left(33^{\circ} \mathrm{C}\right)$ temperature for transgene expression in the presence of $\mathrm{BDNF}$ $(0.2 \mathrm{ng} / \mathrm{ml})$. Closed squares: development of neuron-like cells after addition of BDNF at the non-permissive $\left(37^{\circ} \mathrm{C}\right)$ temperature for transgene expression in the presence of BDNF $(0.2 \mathrm{ng} / \mathrm{ml})$. The criteria for neuronlike cells is positive reaction with the $\alpha \mathrm{NF}$ antibody (see Experimental procedures). The BDNF enhances the emergence of neuron-like cells even at the permissive temperature. Cell counts were those in a total of six randomly sampled fields labelled with $\alpha \mathrm{NF}$ antibody (triplicate cultures were counted). Each point is the average of cells in the three cultures \pm SEM.

two cell isolates were quite different from one another. One of the putative clones was comprised of quite small cells and the other of rather large cells with an entirely different morphology, extensive cytoplasm and many stress fibres within the cells. Further characterization of these cell isolates and differentiation of these cells at the non-permissive temperature will be necessary before we can draw any conclusions about their cell fates.

Putative clones expressing Pax-2 can be used for transplant studies into embryos and for in vitro analysis of downstream targets of this gene as well as the factors that affect Pax-2 expression. Studies are presently underway to examine interactions between $\mathrm{Pax}-2$ and bone morphogenetic protein family members, including BMP-4,,$^{23,32,43,54,70,71}$ that have interesting expression patterns in the developing otocyst. ${ }^{54}$ The en-expressing cell lines can be used for studies of interactions between engrailed and other interacting molecules, such as those of the wint family ${ }^{17}$ that may play a role in ear development. Because these cells closely reflect the expression patterns and timing of genes that may be involved in inner ear development in the embryo, they are promising models to determine the environmental cues that affect their expression in vivo and in vitro and to discover their functional role in the process of correct formation and function of the inner ear. 
Neuron-like cells appear in cultures at the non-permissive temperature and in response to retinoic acid and neurotrophic factors

It will be interesting to determine whether any of the cells that appear in the Immortomouse cell isolates at $37^{\circ} \mathrm{C}$ bears a resemblance to the putative mechanosensory hair cells isolated from later stage (E day 15) Immortomouse heterozygotic embryos as described by Holley's group. ${ }^{40}$ It is possible that hair cell precursors can be isolated from these very early stage otocysts, but they may need to be grown in the presence of supporting cells or specific cytokines in order to develop as far as the cells in the mixed cell cultures. ${ }^{40}$

One of the quail otocyst cell lines assumes a neuronal morphology when exposed to retinoic acid (RA). Differentiation of other quail otocyst cell lines also occurs in RA, producing other cell types which we are in the process of identifying and characterizing. Retinoic acid causes neural crest (NC) cells to differentiate into neurons both in vivo and in vitro, ${ }^{19,35}$ but its effects on the very early development of the inner ear have not been studied in any great detail. Represa et al ${ }^{67}$ have reported that treatment of stage 18 chick embryos with RA (between 1 and $10 \mathrm{nM}$ ) induced the precocious differentiation of secretory epithelium, the tegmentum vasculosum and endolymphatic sac as well as early sensory and supporting epithelia. The authors suggested that RA may have a role in controlling the early development of the inner ear through its effect on $c$-fos expression. ${ }^{67}$ These experiments were done on whole stage 18 otocysts, so precocious development of, e.g. sensory tissues could be identified by their location. However, our studies were done on isolated cloned cell lines, the identification of which must await application of appropriate markers.

At higher concentrations, RA has toxic effects on the hindbrain and the neural crest, which subsequently lead to truncation of the developmental program in the otocyst (see our recent review ${ }^{24}$ as well as the discussion by Corey and Breakefield ${ }^{13}$ ). Development of the cochlea in vitro also is affected by RA. ${ }^{51}$ When E13-16 mouse cochleae were maintained in explant cultures, the addition of 10nM RA at E14 promoted the development of extra hair cells. ${ }^{51}$ In the normal cochlea, there are one inner hair cell and from three to five outer hair cells in each cross-section; treated cultures had a $60 \%$ increase, with as many as two inner hair cells and from six to ten outer hair cells per section. Most of these extra hair cells were born before E14. These results suggest that the fate of existing cells can be changed, but that RA does not stimulate proliferation of precursor cells in this system. The developing mouse cochlea also contains RA from day E14 to P0. ${ }^{51}$ We are presently characterizing RA-responsiveness in IMO cell isolates.

One of the IMO cell isolates is responsive to $\mathrm{BDNF}^{7}$ at relatively low concentration $(0.01 \mathrm{ng} / \mathrm{ml})$ [Fig. $4(\mathrm{~J})$ and Fig. 5(F)]. Both BDNF and NT3 are known to have mitogenic effects on cochleovestibular neurons ${ }^{75}$ and, later in development, enhance the survival of both vestibular and spiral ganglion neurons. ${ }^{3,10,15,65,75}$ It is interesting that BDNF at the range of concentrations tested promoted differentiation of this cell isolate rather than its proliferation. Studies presently are underway to examine these cells for trkB receptors, ${ }^{25,75}$ as well as other nerve growth factor (NGF) receptors. ${ }^{9}$

\section{Dependence of the cell isolates on the presence of other cell types for differentiation}

Because the majority of cells we have examined are putative clones, grown from what we believe to be a single cell isolated by FACS cloning, we do not know what possible differentiation patterns might result if we were to combine the isolated cell derivatives. It is certainly possible that further differentiation of many of these lines might be dependent on the presence of other cell types or factors that we are presently incapable of identifying. In addition, several of the differentiable cell isolates can be used for subtractive hybridization schemes or differential display (see report by the Lomax and other groups in this volume). Such studies undoubtedly will provide a means of exploring the roles of genes important for inner ear development. It is possible also to perform differential display on IMO mixed cell cultures at the permissive and non-permissive temperatures, where a great many cell types undergo differentiation in the presence of the whole panoply of inner ear cells. This type of experiment might well lead to promising results that then can be used to direct functional studies in the embryo.

\section{Future uses of characterized otocyst cell lines}

Characterized otocyst cell lines also can be used for transplantation into embryos, to determine whether the embryonic environment can interact with them "normally". Such defined populations 
can then be used to determine the influence of the environment on otocyst-specific gene expression. Transformed quail otocyst lines that do not produce active Rous sarcoma virus also can be used in short-term transplantation experiments to determine cell fate at the non-permissive temperature. The non-permissive temperature is quail or mouse body temperature; incubator temperature is regulated to achieve the permissive temperature 36.5 (quail) and $33^{\circ} \mathrm{C}$ (Immortomouse). Xenografts of Immortomouse otocyst cells can be placed into chick or quail embryos since xenografting of mouse tissue into avian hosts has long been successful. ${ }^{8.11,66.69 .73 .74}$

The Immortomouse otocyst cell isolates assume different morphologies depending on the substrate on which they are grown (Fig. 5). Cell-substrate interactions may therefore be important for cellular differentiation. Identifying the substrates that alter the differentiation program in vitro will allow us to examine embryos for the presence of these molecules in vivo. Isolated and characterized cell lines also eventually can be used as vehicles for the introduction of vectors containing genes that are not normally expressed in these cells. One can then discover which growth factors, substrates or cellcell interactions are necessary to induce differentiation in these auditory cell lines in vitro, apart from the temperature shift. Discovering these cues in a culture system that can be manipulated and analyzed will be critical to discovering the molecular basis of these cells' differentiation in vivo. Since the immortalized otocyst cell derivatives can be characterized in vitro, information obtained in such experiments can subsequently be used to design experiments in the embryo.

Acknowledgements-This work was supported by NSF grants BNS8910987 and IBN9219666, NIH grant RO1NS31641, and a University of Michigan Office of the Vice-President for Research grant to KFB; and graduate research fellowships from the NIH and NSF to AIK. We wish to thank Dr Mark Noble, Ludwig Institute, London, for many helpful discussions, Drs Mary Hutson and Margaret I. Lomax for a critical reading of the manuscript, P. B. Jewett for preparing the manuscript and Michelle West and M. M. Field for expert technical assistance.

\section{REFERENCES}

1. Anniko M. (1985) Hair cell differentiation following tissue interactions for induction of otocyst morphogenesis. Arch Otorhinolaryngol. 242, 287-294.

2. Anniko M., Nordemar H., Spangberg M. L. and Schacht J. (1981) Biochemical studies on the embryonic development of the mammalian inner ear in organ culture. Arch Otorhinolaryngol. 230, 237-243.

3. Avila M. A., Varela-Nieto I., Romero G., Mato J. M., Giraldez F., Van De Water T. R. and Represa J. (1993) Brain-derived neurotrophic factor and neurotrophin-3 support survival and neuritogenesis response of developing cochleovestibular ganglion neurons. Dev. Biol. 159, 266-275.

4. Barald K. F. (1989) Culture conditions affect the cholinergic development of an isolated subpopulation of chick mesencephalic neural crest cells. Dev. Biol. 135, 349-366.

5. Barald K. F. (1988) Monoclonal antibodies made to chick mesencephalic neural crest cells and to ciliary ganglion neurons identify a common antigen on the neurons and a neural crest subpopulation. J. Neurosci. Res. 21, 107-118.

6. Barald K. F. (1988) The antigen recognized by monoclonal antibodies to mesencephalic neural crest and to ciliary ganglion neurons is involved in the high affinity choline uptake mechanism in these cells. J. Neurosci. Res. 21, 119-134.

7. Barde Y.-A., Edgar D. and Thoenen H. (1982) Purification of a new neurotrophic factor from mammalian brain. EMBO J. 1, 549-553.

8. Bather R., Becker B. C., Contreras G. and Furesz J. (1985) Heterotransplantation studies with tissue culture cell lines in various animal and, in vitro, host systems. $J$. Biol. Stand. 13, 13-22.

9. Bernd P. and Represa J. (1989) Characterization and localization of nerve growth factor receptors in the embryonic otic vesicle and cochleovestibular ganglion. Dev. Biol. 134, 11-20.

10. Bruce L. L., Kingsley J. J., Nichols D. H. and Fritzsch B. (1997) The development of vestibulocochlear efferents and cochlear afferents in mice. Intl J. Dev. Neurosci. 15, 671-692.

11. Cairns J. M. (1965) Development of grafts from mouse embryos to the wing bud of the chick embryo. Dev, Biol. 12, 3652.

12. Chambers T. J., Owens J. M., Hattersley G., Jat P. S. and Noble M. D. (1993) Generation of osteoclast-inductive and osteoclastogenic cell lines from the W2KbtsA58 transgenic mouse. Proc. natn Acad. Sci. U.S.A. 90, 5578-5582.

13. Corey D. P. and Breakefield X. O. (1994) Transcription factors in inner ear development. Proc. natn Acad. Sci. U.S.A. 91, 433-436.

14. Couly G. F., Coltey P. M. and Le Douarin N. M. (1993) The triple origin of skull in higher vertebrates: a study in quailchick chimeras. Development 117, 409-429.

15. Davies A. M., Thoenen H. and Barde Y.-A. (1986) the response of chick sensory neurons to brain-derived neurotrophic factor. $J$. Neurosci. 6, 1897-1904.

16. Davis C. A., Holmyard D. P., Millen K. J. and Joyner A. L. (1991) Examining pattern formation in mouse, chicken and frog embryos with an En-specific antiserum. Development 111, 287-298.

17. Dougan S. and DiNardo S. (1992) Drosophila wingless generates cell type diversity among engrailed expressing cells. Nature 360, 347-350.

18. Dressler G. R., Deutsch U., Chowdhury K., Nornes H. O. and Gruss P. (1990) Pax-2, a new murine paired-boxcontaining gene and its expression in the developing excretory system. Development 109, 787-795.

19. Dupin E. and Le Douarin N. M. (1995) Retinoic acid promotes the differentiation of adrenergic cells and melanocytes in quail neural crest cultures. Dev. Biol. 168, 529-548. 
20. Ehler E., Jat P. S., Noble M. D., Citi S. and Draeger A. (1995) Vascular smooth muscle cells of H-2Kb-tsA58 transgenic mice. Characterization of cell lines with distinct properties. Circulation 92, 3289-3296.

20a. Ernfors R., Van De Water T., Loring J. and Jaenisch R. (1995) Complementary roles of BDNF and NT-3 in vestibular and Auditory development. Neuron 14, 1153-1164.

21. Fjose A., Eiken H. G., Njolstad P. R., Molven A. and Hordvik I. (1988) A zebrafish engrailed-like homeobox sequence expressed during embryogenesis. FEBS Lett. 231, 355-360.

22. Fontaine-Perus J. C., Chanconie M., Le Douarin N. M., Gershon M. D. and Rothman T. P. (1989) Mitogenic effect of muscle on the neuroepithelium of the developing spinal cord. Development 107, 413-422.

23. Francis-West P. H., Tatla T. and Brickell P. M. (1994) Expression patterns of the bone morphogenetic protein genes Bmp-4 and Bmp-2 in the developing chick face suggest a role in outgrowth of the primordia. Dev. Dyn. 201, 168-178.

24. Fritzsch B., Barald K. F. and Lomax M. I. Embryology of the vertebrate ear. In Handbook of Auditory Physiology (eds Popper A. N., Rubel E. and Fay R.). Springer Verlag (in press).

25. Fritzsch B., Sarai P. A., Barbacid M. and Silos-Santiago I. (1997) Mice with a targeted disruption of the neurotrophin receptor $t r k \mathrm{~B}$ lose their gustatory ganglion cells early but do develop taste buds. Intl J. Dev. Neurosci. 15, 563-576.

26. Gardner C. A., Darnell D. K., Poole S. J., Ordahl C. P. and Barald K. F. (1988) Expression of an engrailed-like gene during development of the early chick nervous system. J. Neurosci. Res. 21, 426-437.

27. Gardner C. A. and Barald K. F. (1991) The cellular environment controls the expression of engrailed-like protein in the cranial neuroepithelium of quail/chick-chimeric embryos. Development 113, 1037-1048.

28. Gardner C. A., Kavka A. I. and Barald K. F. (1989) Expression of an engrailed-like gene in the nervous system and head mesenchyme of the chick embryo. J. Cell Biol. 109, 59a.

29. Gardner C. A. and Barald K. F. (1992) Expression patterns of engrailed-like protein in the chick embryo. Det. Dyn. 193, 370-388.

30. Groves A. K., Entwistle A., Jat P. S. and Noble M. (1993) The characterization of astrocyte cell lines that display properties of glial scar tissue. Dev. Biol. 159, 87-104.

31. Hamburger V. and Hamilton V. L. (1951) A series of normal stages in the development of the chick embryo. J. Morphol. $\mathbf{8 8}, 49-92$.

32. Hemmati-Brivanlou A. and Thomsen G. H. (1995) Ventral mesodermal patterning in Xenopus embryos: expression patterns and activities of BMP-2 and BMP-4. Dev. Genet. 17, 78-89.

33. Hemmati-Brivanlou A., Torre J. R., Holt C. and Richard M. (1991) Cephalic expression and molecular characterization of Xenopus En-2. Development 111, 715-724.

34. Hemond S. G. and Morest D. K. (1991) Ganglion formation from the otic placode and the otic crest in the chick embryo: mitosis, migration, and the basal lamina. Anat. Embryol. 184, 1-13.

35. Henion P. D. and Weston J. A. (1994) Retinoic acid selectively promotes the survival and proliferation of neurogenic precursors in cultured neural crest cell populations. Dev. Biol. 161, 243-250.

36. Henry C., Marbrook J, Vann D. C., Kodlin D. and Wofsy, C. (1980) Limiting dilution analysis. In Selected Methods in Cellular Immunology (eds Mishell B. and Shiigi S. M.), pp. 138-152. W. H. Freeman \& Co, San Francisco.

37. Herman P., Cassigena R., Friedlander G., Soler P., Grodet A., Tran Ba Huy P. and Amiel C. (1993) Middle ear cell line that maintains vectorial electrolyte transport. J. Cell Physiol. 154, 615-622.

38. Hinterberger T. J. and Barald K. F. (1990) Fusion between myoblasts and mature muscle fibers promotes remodeling of fibers into myotubes in vitro. Development 109, 139-148.

39. Holland P. W. H. and Williams N. A. (1990) Conservation of engrailed-like homeobox sequences during vertebrate evolution. FEBS Lett. 277, 250-252.

40. Holley M. C., Nishida Y. and Grix N. (1997) Conditional immortalisation of hair cells from the inner ear. Intl J. Dev Neurosci. 15, 541-552.

41. Jat P. S., Noble M. D., Ataliotis P., Tanaka Y., Yannoutsos N., Larsen L. and Kioussis D. (1991) Direct derivation of conditionally immortal cell lines from an W2Kb-tsA58 transgenic mouse. Proc. natn Acad. Sci. U.S.A. 88, 5096-5100.

42. Jat P. S. and Sharp P. A. (1989) Cell lines established by a temperature-sensitive simian virus 40 large T-antigen gene are growth restricted at the nonpermissive temperature. Mol. Cell Biol. 9, 1672-1681.

43. Jones C. M., Lyons K. M. and Hogan B. L. (1991) Involvement of bone morphogenetic protein-4 (BMP-4) and Vgr-1 in morphogenesis and neurogenesis in the mouse. Development 111, 531-542.

44. Jove R., Garber E. A., Iba H. and Hanafusa H. (1986) Biochemical properties of p $60 \mathrm{v}$-src mutants that induce different cell transformation parameters. J. Virol. 60, 849-857.

45. Jove R., Mayer B. J., Iba H., Laugier D., Poirier F., Calothy G., Hanafusa T. and Hanafusa H. (1986) Genetic analysis of p60v-sre domains involved in the induction of different cell transformation parameters. J. Virol. 60, 840-848.

46. Joyner A. L., Kornberg T., Coleman K. G., Cox D. R. and Martin G. R. (1985) Expression during embryogenesis of a mouse gene with sequence homology to the Drosophila engrailed gene. Cell 43, 29-37.

47. Joyner A. L. and Martin G. R. (1987) En-1 and En-2, two mouse genes with sequence homology to the Drosophila engrailed gene: expression during embryogenesis. Genes Dev. 1, 29-38.

48. Kalinec, R., Kalinec G. and Kachar B. (1996) Development of organ of Corti and stria vascularis cell lines from transgenic mice. 19th ARO Midwinter Meeting. Abstr. 577.

49. Kavka A. I., Baizer L., Gutmann D. H. and Barald, K. F. Differential expression of neurofibromatosis I (NF1) message and protein during neural crest cell migration and differentiation (submitted).

50. Kavka, A. I., Shih, T. S., Jacks, T. and Barald, K. F. Neurofibromin affects the differentiation of embryonic stem cells into early neurons (submitted).

51. Kelley M. W., Xu X. M., Wagner M. A., Warchol M. E. and Corwin J. T. (1993) The developing organ of Corti contains retinoic acid and forms supernumerary hair cells in response to erogenous retinoic acid in culture. Development 119, $1041-1053$.

52. Kershaw T. R., Rashid-Doubell F. and Sinden J. D. (1994) Immunocharacterisation of H-2K b-tsA58 transgenic mouse hippocampal neuroepithelial cells. NeuroReport 5, 2197-2200.

53. Li C. W., Van De Water T. R. and Ruben R. J. (1978) The fate mapping of the eleventh and twelfth day mouse otocyst: an in vitro study of the sites of origin of the embryonic inner ear sensory structures. J. Morphol. 157, 249-267.

54. Lindberg K. H., Victor J. C., Lewis J. E., Nguyen-Luu D., Ng A., Germiller J., Siram S., Kudilico K. T., Poniatowski A. and Barald K. F. Plasticity of gene expression in the developing chick inner ear (submitted). 
55. Lindberg K. H., Dressler G. R. and Barald K. F. (1995) The cellular environment controls the expression of Pax-2 protein in the otocyst during development of the chick inner ear. Molecular Development of the Ear, Meeting Abstr., Bethesda, MD, U.S.A.

56. Martinez S., Marin F., Nieto M. A. and Puelles L. (1995) Induction of ectopic engrailed expression and fate change in avian rhombomeres: intersegmental boundaries as barriers. Mech. Dev. 51, 289-303.

57. McPhee J. R., Van de Water T. R. (1986) Epithelial-mesenchymal tissue interactions guiding otic capsule formation: the role of the otocyst. J. Embryol. Expl Morphol. 97, 1-24.

58. Meza G., Lopez I., Paredes M. A., Penaloza Y. and Boblano A. (1989) Cellular target of streptomycin in the internal ear. Acta Otolaryngol. (Stockh.) 107, 406-411.

59. Michel D., Gillet G., Volovitch M., Pessac B., Calothy G. and Brun G. (1989) Expression of a novel gene encoding a 51.5 precursor protein in induced by different retroviral oncogenes in quail neuroretinal cells. Oncogene Res. 4, 127-136.

60. Morgan J. E., Beauchamp J. R., Pagel C. N., Peckham M., Ataliotis P., Jat P. S., Noble M. D., Farmer K. and Partridge T. A. (1994) Myogenic cell lines derived from transgenic mice carrying a thermolabile $T$ antigen: a model system for the derivation of tissue-specific and mutation-specific cell lines. Dev. Biol. 162, 486-498.

61. Noble M., Groves A. K., Ataliotis P., Ikram Z. and Jat P. S. (1995) The W2KbtsA58 transgenic mouse: a new tool for the rapid generation of novel cell lines. Transgenic Res. 4, 215-225.

62. Nornes H. O., Dressler G. R., Knapik E. W., Deutsch U. and Gruss P. (1990) Spatially and temporally restricted expression of Pax 2 during murine neurogenesis. Development 109, 797-809.

63. Oesterle E. C., Tsue T. T., Reh T. A. and Rubel E. M. (1993) Hair-cell regeneration in organ cultures of the postnatal chicken inner ear. Hearing Res. 70, 85-108.

64. Patel N. H., Martin-Blanco E., Coleman K. G., Poole S. J., Ellis M. C., Kornberg T. B. and Goodman C. S. (1989) Expression of engrailed proteins in arthropods, annelids, and chordates. Cell 58, 955-968.42.

65. Pirvola U., Ylikoski J., Paigi J., Lethonen E., Arumae U. and Saarma M. (1992) Brain-derived neurotrophic factor and neurotrophin 3 mRNAs in the peripheral target fields of developing inner ear ganglia. Proc. natn Acad. Sci. U.S.A.89, 9915-9919.

66. Pugin E. (1973) Sur le comportement des troncons du tube neural et de la chorde d'embryon de souris greffes à la place des organes homologues chez l'embryon de poulet. C.r. Acad. Sci. Hebd. Séances Acad. Sci. D 276, 3477-3480.

67. Represa J., Sanchez A., Miner C., Lewis J. and Giraldez F. (1990) Retinoic acid modulation of the early development of the inner ear is associated with the control of c- fos expression. Development 110, 1081-1090.

68. Robertson N. G., Khetarpal U., Gutierrez-Espeleta G. A., Bieber F. R. and Morton C. C. (1994) Isolation of novel and known genes from a human fetal cochlear cDNA library using subtractive hybridization and differential screening. Genomics 23, 42-50.

69. Rogulska T., Ozdzenski W. and Komar A. (1971) Behaviour of mouse primordial germ cells in the chick embryo. $J$. Embryol. Expl Morphol. 25, 155-164.

70. Sasai Y., Lu B., Steinbeisser H. and De Robertis E. M. (1995) Regulation of neural induction by the Chd and Bmp-4 antagonistic pattering signals in Xenopus. Nature 376, 333-336.

71. Schmidt J. E., Suzuki A., Ueno N. and Kimelman D. (1995) Localized BMP-4 mediates dorsal/ventral pattering in the early Xenopus embryo. Dev. Biol. 169, 37-50.

72. Shaw G., Osborn M. and Weber K. (1986) Reactivity of a panel of neurofilament antibodies on phosphorylated and dephosphorylated neurofilaments. Eur. J. Cell Biol. 42, 1-9.

73. Thiebold J. and Karcher-Djuricic V. (1972) Developpement des ebauches dentaires presomptives de souris greffees dans le coelome de l'embryon de poulet. C.r. Acad. Sci. Hebd. Séances Acad. Sci. D 274, 274-276.

74. Tio K. L., Cuminge D. and Wolff E. (1968) Sur l'innervation de greffons implantes dans l'embryon de poulet. C.r. Acad. Sci. Hebd. Séances Acad. Sci. D 266, 4-7.

75. Vazquez E., Van de Water T. R., Del Valle M., Vega J. A., Staecker H. and Giraldez Rand Represa J. (1994) Pattern of trkB protein-like immunoreactivity in vivo and the in vitro effects of brain-derived neurotrophic factor (BDNF) on developing cochlear and vestibular neurons. Anat. Embryol. 189, 157-167.

76. Van de Water T. and Ruben R. J. (1974) Growth of the inner ear in organ culture. Ann. Otol. Rhinol. Laryngol. 83, 811816.

77. Wassef M., Bally-Cuif L. and Alvarado-Mallart R. M. (1993) Regional specification during cerebellar development. Perspect. Dev. Neurobiol. 1, 127-132.

78. Whitehead R. H. and Joseph J. L. (1994) Derivation of conditionally immortalized cell lines containing the Min mutation from the normal colonic mucosa and other tissues of an "Immortomouse"/Min hybrid. Epithel. Cell Biol. 3, 119-125.

79. Whitehead R. H., VanEeden P. E., Noble M. D., Ataliotis P. and Jat P. S. (1993) Establishment of conditionally immortalized epithelial cell lines from both colon and small intestine of adult $\mathrm{H}-2 \mathrm{~Kb}$-tsA58 transgenic mice [published erratum appears in Proc. natn Acad. Sci. U.S.A. (1993) 15:90(14): 6894]. Proc. nain. Acad. Sci. U.S.A. 90, $587-591$.

80. Wilson P. A., Hemmati-Brivanlou A. (1995) Induction of epidermis and inhibition of neural fate by Bmp-4. Nature 376, 331-333.

81. Wolff A., Houdayer M., Chillet D., de Nechaud B. and Denoulet P. (1994) Structure of the polyglutamyl chain of tubulin: occurrence of alpha and gamma linkages between glutamyl units revealed by monoreactive polyclonal antibodies. Biol. Cell 81, 11-16.

82. Wolff A., de Nechaud B., Chillet D., Mazarguil H., Desbruyeres E., Audebert S., Edde B., Gros F. and Denoulet P. (1992) Distribution of glutamylated alpha and beta-tubulin in mouse tissues using a specific monoclonal antibody, GT335. Eur. J. Cell Biol. 59, 425-432.

83. Gong T.-W. L, Hegeman A. D., Shin J. J., Lindberg K. H., Barald K. F. and Lomax M. I. (1996) Novel genes expressed in the chick otocyst during development: identification using differential display of RNA. Intl J. Dev. Neurosci. 15, 585594. 